Савинкова Д.В., Лях Т.И.

Сравнительный анализ развития особенностей восприятия у детей младшего школьного возраста с задержкой психического развития на констатирующем и контрольном этапах исследования

\author{
Savinkova D.V., Lyakh T.I. \\ Comparative analysis of the development features of perception \\ in primary school children with mental retardation on \\ ascertaining and control stages of the study
}

Статья посвещена сравнительному анализу особенностей развития восприятия у детей младшего школьного возраста с задержкой психического развития на констатирующем и контрольном этапах исследования. В статье представлены диагностическая программа,её результаты и коррекционная программа для развития восприятия у детей с задержкой психического развития

Ключевые слова: восприятие, дети с задержкой психического развития

\section{Савинкова Дарья Владимировна}

Студент

Тульский государственный педагогический университет им. Л.Н. Толстого

г. Тула, пр. Ленина, 125

\section{Лях Татьяна Ильинична}

Кандидат психологических наук, доцент Тульский государственный педагогический университет им. Л.Н. Толстого

2. Тула, пр. Ленина, 125
The article is dedicated to the comparative analysis of peculiarities of perception in primary school children with mental retardation on ascertaining and control stages of the study. The paper presents the diagnostic program, its results and the correction program for the development of perception in children with mental retardation

Key words: perception, children with mental retardation

\section{Savinkova Daria Vladimirovna}

Student

Tula state pedagogical university named L.N. Tolstoy Tula, Lenina ave., 125

\section{Lyakh Tatiana Ilinichna}

Candidate of Psychological Sciences, Associate

Professor

Tula state pedagogical university named L.N. Tolstoy Tula, Lenina ave., 125

Восприятием (перцепцией) называется отражение в сознании человека предметов или явлений в совокупности их свойств и частей при их непосредственном воздействии на органы чувств [1]. В ходе восприятия происходит упорядочение и объединение отдельных ощущений в целостные образы вещей и событий. Процесс восприятия протекает в связи с другими психическими про- 
цессами личности: мышлением, речью, чувствами, волей. В результате воздействия определенных предметов и явлений окружающего мира на наши органы чувств формируется предметность восприятия. Наглядный образ восприятия запоминается, вспоминается, представляется. Единство психических процессов обусловлено тем, что все они проявляются в едином процессе жизнедеятельности человека как результат взаимодействия человека с окружающей его средой [2]. Этим единством обусловлена актуальность изучения восприятия в младшем школьном возрасте, когда произвольность познавательных процессов развивается и у ребенка постепенно формируется внутренняя позиция ученика.

Целью нашего исследования является изучение и корректирование особенностей восприятия детей младшего школьного возраста с задержкой психического развития.

Мы предполагаем, что для развития особенностей восприятия детей младшего школьного возраста с задержкой психического развития необходимо в коррекционно-развивающей работе, основанной на результатах диагностического исследования включать развивающие игры и упражнения по следующим направлениям :

1) Зрительное восприятие;

2) Слуховое восприятие;

3) Пространственные представления;

В состав диагностической программы вошли следующие методики: Методика «Нелепицы» (Автор С. Забрамная), Методика «Наложенные изображения» (Автор А.Р. Лурия), Методика «Домик» (Автор Н.И. Гуткина), Методика « Незавершенные изображения» (Автор М.М. Семаго), Методика исследования слухового восприятия (Автор Л.С.Цветкова).

Исследование проводилось на базе ГОУ Т0 «Тульская школа для обучающихся с ограниченными возможностями здоровья №4» города Тулы.

В исследовании принимали участие 2 мальчика и 3 девочки в возрасте 911 лет.

В ходе проведения диагностической программы были выявлены следующие результаты:

Результаты исследования элементарных образных представлений об окружающем мире, полученные с помощью методики «Нелепицы» показали, что у $40 \%$ испытуемых очень низкий уровень развития общего восприятия при этом у $60 \%$ младших школьников с задержкой психического развития этот уровень низкий.

Анализ результатов, полученных с помощью методики «Наложенные изображения» показал, что очень низкий и низкий уровень зрительного восприятия наблюдается у 40\% младших школьников с задержкой психического развития, у 20\% детей из данной выборки наблюдается средний уровень развития зрительного восприятия.

Исследования, выполненные с помощью методики «Домик» показали, что у всех испытуемых имеется низкий уровень развития пространственного восприятия. 
Данные исследования с помощью методики «Незавершенные изображения» установили, что у 40\% младших школьников с задержкой психического развития имеется низкий уровень развития зрительного восприятия. При этом у 40\% детей наблюдается очень низкий уровень развития зрительного восприятия, у 20\% младших школьников с задержкой психического развития установлен средний уровень развития зрительного восприятия.

Методика исследования слухового восприятия Л.С. Цветковой позволила выявить следующие данные: у 20\% испытуемых наблюдается средний уровень развития слухового восприятия, у $80 \%$ младших школьников с задержкой психического развития присутствует низкий развития слухового восприятия.

Обобщая полученные с помощью диагностической программы результаты, можно констатировать преобладание низкого и очень низкого уровней развития восприятия в данной выборке младших школьников с задержкой психического развития.

нами была составлена коррекционно-развивающая программа по развитию восприятия у детей младшего школьного возраста с задержкой психического развития. Программа состоит из 12 занятий. При соблюдении режима проведения (2 занятия в неделю) цикл рассчитан на 1,5 месяца. Каждое занятие рассчитано на 30 минут и содержит 5 упражнений. При необходимости, каждое упражнение можно повторять несколько раз.

Диагностирование особенностей восприятия детей младшего школьного возраста с задержкой психического развития на этапе контрольной диагностики проходило с использованием тех же методик, что и на этапе констатирующего эксперимента.

В ходе сравнительного анализа результатов, полученных на констатирующем и контрольном этапах исследования, выявлены следующие изменения. Методика «Нелепицы» показала, что на констатирующем этапе исследования у детей преобладает низкий уровень развития общего восприятия, на контрольном этапе преобладает средний уровень развития общего восприятия. Методика « Наложенные изображения» показала, что на констатирующем этапе у детей преобладает очень низкий и низкий уровни развития зрительного восприятия. На контрольном этапе у испытуемых преобладает высокий и средний уровни развития зрительного восприятия. Методика исследования слухового восприятия показала, что на констатирующем этапе исследования преобладает низкий уровень развития слухового восприятия. На контрольном этапе у детей преобладает средний уровень слухового восприятия, также присутствует высокий и очень высокий уровни развития слухового восприятия. Методика «Незавершенные изображения» показала, что на констатирующем этапе исследования у детей выявлен очень низкий и низкий уровни развития зрительного восприятия .На контрольном этапе исследования у младших школьников с задержкой психического развития выявлен преимущественно средний, но также присутствует и высокий уровни развития зрительного восприятия. Методика «Домик» показала, что на констатирующем этапе исследования у всех испытуемых низкий уровень развития пространственного восприятия. В ходе проведения 
контрольного этапа исследования у детей отмечен средний уровень развития пространственного восприятия.

Таким образом на сравнительном этапе исследования прослеживается положительная динамика, что говорит об эффективности коррекционно-развивающей работы, направленной на развития уровня восприятия.

\section{Список используемых источников:}

1. Петровский А.В. Общая психология. М.: Просвещение, 2007. 479 с.

2. Карандашев Ю.Н. Возрастная функционально-стадиальная периодизация психического развития детей:дис. д-ра психол. наук: 19.00.07. Ленинград, 1991. 433 с.

3. Petrovsky A.V. General psychology. M.: Education, 2007. 479 p.

4. Karandashev U.N. Age functionally stadial periodization of mental development of children: Dis. Doctor of Psychology: 19.00.07. Leningrad, 1991. 433 p.

(C) 2016, Савинкова Д.В., Лях Т.И. Сравнительный анализ развития особенностей восприятия у детей младшего школьного возраста с задержкой психического развития на констатирующем и контрольном этапах исследования
(C) 2016, Savinkova D.V., Lyakh T.I.

Comparative analysis of the development features of perception in primary school children with mental retardation on ascertaining and control stages of the study 